\title{
EFFECT OF STORE IMAGE ON LOYALTY STORE THROUGH STORE SATISFACTION IN ISLAMIC SWALAYAN STORES
}

\author{
Muhammad Arief $^{1)}$, Dwi Hendro Widayatmoko ${ }^{1)}$ \\ 1) Universitas Esa Unggul, Jakarta, Indonesia \\ Corresponding Author: m.ariefdsn@ gmail.com
}

\begin{abstract}
Purchasing a product or shopping in an Islamic supermarket or store is something that is unique with many factors which will affect the consumer. One of the factor that influences consumer when choosing to shop in a certain store is the image that arises and attaches to that store. A good image of the store will affect the consumer to keep shopping and become loyal to the store. Consumer satisfaction when shopping in a store is also a factor that influences the loyalty of the consumer to that particular store. Furthermore, a good image plays an important on making the consumer satisfied, and together will influence the consumer to become loyal to that store.
\end{abstract}

Keywords: store image, store loyalty, store satisfaction.

\section{INTRODUCTION}

Islamic religion, which is now experiencing turbulence with various issues such as Islamophobia, radicalism, terrorism, and so on, on the other hand turns out to be the fastest growing religion compared to other religions. According to research conducted by the Pew Research Center (2015), Islam in 2015 is estimated to be shared by around 1.8 billion people or $24 \%$ of the total world population, in 2060 it is estimated that it will increase to around 3 billion people or $31 \%$ of the total population of the world, and at the end of this century will be the most widely practiced religion in the entire world.

The development of Islam has an impact on the global business world, where the Muslim market is calculated by business people as a profitable market segment. Industries that are starting to target Muslim markets include banking or finance. In 2015 the first Sharia Bank in Germany, KT Bank AG was established, before other Islamic banks had been established in the UK and France. In addition, the UK also became the first non-Muslim country to sell sukuk or Islamic bonds, which were later followed by other countries such as Luxembourg, South Africa and Hong Kong (CNN Indonesia, 2015).

The development of Islamic business does not only occur in non-Muslim countries. Indonesia, which has long had a majority Muslim population, feels the same, among others, in the Muslim retail industry.

At present the industry that is developing along with the development of the Islamic world is retail, especially the Islamic Supermarkets segment. Now supermarkets are starting to emerge that try to apply Islamic values in selling products, for example Tip Top, Ahad Mart, Alifa Mart, Madinah Super Market, and even in 2016 Lulu Hypermarket, a network supermarket from the United Arab Emirates, has been established. The object of this research is about one of the Islamic Supermarkets in Bandung, namely Super Mini Market (SMM).

SMM is an Islamic Supermarket that is managed by the Daarut Tauhiid Foundation assisted by Aa Gym, located in Gegerkalong, Bandung, which is the area of the Daarut Tauhiid Islamic Boarding School. From the product side, SMM offers products that are not much different from other supermarkets in general, namely people's daily needs. This causes QMS to compete directly with other supermarkets, such as Indomaret and Alfamart, which have advantages such as extensive networks and large capital.

The thing that distinguishes SMM from competitors is that this supermarket strives to display an Islamic store image by applying a number of regulations, namely: (1) SMM does not sell illicit goods such as alcohol, or does not even sell cigarettes, contraception, and other products that do not according to Islamic values, (2) cashiers for men and women are separated, (3) each time the SMM prayer time is closed, (4) Islamic broadcasts are always played, such as murotal Al-Quran, Islamic music, and tausyiah (Daarut Tauhiid [1]). These regulations are expected to be a competitive advantage and the main attraction for creating store satisfaction in shopping at SMM, which ultimately creates store loyalty.

This study analyzes the effect of store image positioned by SMM on store loyalty through store satisfaction, with the aim of knowing whether the SMM strategy in imaging Islam in its business is successful, thus making store image one of the competitive advantages in winning competition. 


\section{Store Image}

The store image concept is the development of a brand image, first introduced by Martineau [2], which is a definition in the customer's mind of a store according to the properties / attributes of the store so that customers can distinguish between a store and another store. Bloemer and Ruyter [3] define store image as a complexity of consumer perceptions of a store regarding the prominent attributes of the store. In simple terms, Sopiah and Syihabudhin [4] describe store image as the personality of a store. Store image is one of the factors that make a customer make a repeat purchase to a store, after the customer compares the buying experience with expectations (Kunkel and Berry [5]). follows:

The store image element used in this study is as

1. Store atmosphere, is a general atmosphere of a store that involves various kinds of stimulants that are felt by consumers, including store decorations / layouts and products, colors, store lighting, fragrances, music, store employees' appearance, and other stimulants that can influence customers (Sezgin and Küçükköylü [6]).

2. Convenience facility, namely facilities provided in the store such as ATMs, toilets, parking lots that can make customers feel comfortable (Dong-Mo Koo [7]).

3. Price, which is the price of products offered in stores, which is one of the factors of consumer purchasing decisions (Hosseini et al. [8]).

4. Merchandising, which is related to the number of products or brands offered by a store (Dong-Mo Koo [7]), along with the quality of these products (Hosseini et al. [8]).

5. Service quality, namely the quality of service for store employees towards good or friendly customers (Population, 2016).

6. Location, namely the convenience of the location of a store to be reached by customers (Guduk [9]).

\section{Store Loyalty}

Loyal customers are an important goal for marketers long ago, because maintaining customers requires less effort than finding new customers (Knox and Walker [10]). Even Santoso [11] argues that a large number of loyal consumers is a competitive asset for the company. According to Oliver [12], loyalty is a commitment that customers maintain to repurchase or subscribe to a product or service consistently in the future. Bloemer and Ruyter [3] describe store loyalty as someone's promise or commitment to the shop of their choice. According to Kotler and Keller [13], there are 3 dimensions of store loyalty, namely:

1. Word of Mouth, recommend certain products/stores to others.

2. Reject another, choose a particular product / shop compared to other products / stores.
3. Repeat purchasing, re-purchase products / in certain stores.

\section{Store satisfaction}

McQuitty et al [14] said that satisfaction is important in marketing because it can predict purchase behavior. Bitner [15] argues that before customers become loyal, they must be satisfied first. Keller [16] defines satisfaction as a person's feelings of pleasure or disappointment after comparing performance or perceived results compared to expectations. In the context of retail stores, according to Bloemer and Ruyter [3] store satisfaction is the result of subjective evaluations of customers that the selected store is suitable or even better than its expectations. According to Lupiyoadi [17], there are five dimensions of customer satisfaction, namely:

1. product quality, satisfied with the quality of the products offered.

2. quality of service, satisfied with the services provided.

3. emotional, feeling a sense of pride when using a product / shopping at a particular store.

4. price, feel satisfied with the price of the product offered.

5. costs and convenience, do not incur additional costs in buying products (not used).

\section{Inter-Variable Relationships}

Store image that is in accordance with customer expectations will lead to satisfaction. Research by Martenson [18], Theodoridis and Chatzipanagotou [19], and Agustin [20] support this, that store image has an influence on satisfaction.

H1: Store image affects store satisfaction

According to Bloemer and Ruyter [3], if the store image is increasingly preferred by customers, then the store will have more power to the customer. However, Bloemer and Ruyter explained that a definite relationship between store image and loyalty is still not convincing. Some studies failed to find a direct influence between the two variables, among others, by Agustin [20], while other studies gave different results, including Bloemer and Ruyter [3] Dong-Mo Koo [7], Orth and Green [21], and the latest research from Shamsher (2014) which states that store image has an influence on loyalty.

$\mathrm{H} 2$ : Store image influences store loyalty

According to Semuel (2006), customer satisfaction greatly affects the intensity of purchases and buyer behavior to become loyal. His research proves that satisfaction affects loyalty. Several other studies support this, including Dong-Mo Koo [7], Guenzi and Pelloni [22], and Orth and Green [21]. The higher consumer satisfaction in shopping at the store, the more loyal the store will be.

H3: Store Satisfaction affects store loyalty 
Furthermore, a good store image in the customer's perception will lead to satisfaction for the customer and potentially make the customer make a repeat purchase at the store, which in turn has the potential to cause customer loyalty to a store. This shows that satisfaction mediates the relationship between store image to store loyalty, as the results of research by Bloemer and Ruyter [3], Dong-Mo Koo [7], and Orth and Green [21]. Store image can affect customer satisfaction, which then customer satisfaction will affect loyalty to the store.

H4: Store image influences store loyalty through store satisfaction

\section{RESEARCH METHODS}

\section{Research Design}

This study uses causal research, which is to determine the relationship of the independent variable, store image to the dependent variable, namely store loyalty through an intervening variable, namely store satisfaction. Based on the objectives, this research belongs to the hypothesis testing research, with the survey method. The unit of analysis in this study is individuals, and the measurement in this study uses a Likert scale.

\section{Object Research}

The object of this research is Super Mini Market Daarut Tauhiid (SMM) located in Gegerkalong, Bandung.

\section{Population, Samples, and Sampling Techniques}

The population in this study were all people who had shopped in an SMM with an unknown number. The sample in this study amounted to 100 people with the quota sampling method, while the sampling technique used was purposive sampling, with the following criteria:

1. Aged 17 and above

2. Met at SMM, Gegerkalong Bandung

3. Have made a purchase in QMS at least 3 times

\section{Operational Definition of Variables}

Following are the operational definitions of research variables:

Table 1 Operational Definition of Variables

\begin{tabular}{|c|c|c|c|}
\hline Variable & Dimension & Indicator & Scale \\
\hline \multirow[t]{4}{*}{$\begin{array}{l}\text { Store } \\
\text { image } \\
(\mathrm{X})\end{array}$} & $\begin{array}{l}\text { Store Atmosfphere } \\
\text { (Sezgin dan } \\
\text { Küçükköylü, 2014) }\end{array}$ & $\begin{array}{l}\text { SMM has an Islamic } \\
\text { atmosphere }\end{array}$ & \multirow[t]{4}{*}{ Likert } \\
\hline & $\begin{array}{l}\text { Convenience } \\
\text { Facilities } \\
\text { (Dong-Mo Koo, } \\
\text { 2003) }\end{array}$ & $\begin{array}{l}\text { SMM has facilities } \\
\text { such as ATMs, toilets, } \\
\text { parking lots }\end{array}$ & \\
\hline & $\begin{array}{l}\text { Price } \\
\text { (Hosseini et al, } \\
\text { 2014) }\end{array}$ & $\begin{array}{l}\text { The price of products } \\
\text { in SMM is relatively } \\
\text { affordable }\end{array}$ & \\
\hline & Merchandising & $\begin{array}{l}\text { SMM sells a variety of } \\
\text { products and brands }\end{array}$ & \\
\hline
\end{tabular}

\begin{tabular}{|c|c|c|c|}
\hline & $\begin{array}{l}\text { (Dong-Mo Koo, } \\
\text { 2003), (Hosseini et } \\
\text { al, 2014) }\end{array}$ & & \\
\hline & $\begin{array}{l}\text { Service Quality } \\
\text { (Guduk, 2016) }\end{array}$ & $\begin{array}{l}\text { SMM waiters provide } \\
\text { good service }\end{array}$ & \\
\hline & $\begin{array}{l}\text { Location } \\
\text { (Guduk, 2016) }\end{array}$ & $\begin{array}{l}\text { The location of the } \\
\text { SMM is easy to reach }\end{array}$ & \\
\hline \multirow{4}{*}{$\begin{array}{l}\text { Store } \\
\text { satisfaction } \\
\text { (Z) } \\
\text { (Lupiyoadi, } \\
\text { 2001) }\end{array}$} & Product quality & $\begin{array}{l}\text { Customers are satisfied } \\
\text { with the quality of } \\
\text { products offered by } \\
\text { SMM }\end{array}$ & Likert \\
\hline & Service quality & $\begin{array}{l}\text { Customers are satisfied } \\
\text { with the quality of } \\
\text { service provided by } \\
\text { SMM employees }\end{array}$ & \\
\hline & Emotional & $\begin{array}{l}\text { Customers feel proud } \\
\text { to shop at SMM }\end{array}$ & \\
\hline & Price & $\begin{array}{l}\text { Customers are satisfied } \\
\text { with the price of } \\
\text { products offered by } \\
\text { SMM }\end{array}$ & \\
\hline \multirow{3}{*}{$\begin{array}{l}\text { Store } \\
\text { loyalty } \\
\text { (Kotler dan } \\
\text { Keller, } \\
2010 \text { ) }\end{array}$} & Word of Mouth & $\begin{array}{l}\text { Recommend SMM to } \\
\text { others }\end{array}$ & \multirow[t]{3}{*}{ Likert } \\
\hline & Reject Another & $\begin{array}{l}\text { Choosing QMS } \\
\text { compared to other } \\
\text { stores }\end{array}$ & \\
\hline & Repeat Purchasing & $\begin{array}{l}\text { Make a repeat purchase } \\
\text { in SMM }\end{array}$ & \\
\hline
\end{tabular}

Data analysis technique

Test Validity and Reliability

Validity test is done by using product moment correlation coefficient from Karl Pearson, where a statement is said to be valid if the value of $r$ count $>0.361$ (30 respondents), while reliability testing is done using the Alpha coefficient of Cronbach, where the variable is declared reliable if it has a minimum value of 0,6 .

\section{Path Analysis}

The Path Analysis method is used to determine the direct and indirect effects between variables, where the exogenous variables in this study are store image $\mathrm{X}$ (independent variable) and endogenous variable store loyalty Y (dependent variable) and store Satiscfaction Z (intervening variable), with research models as follows:

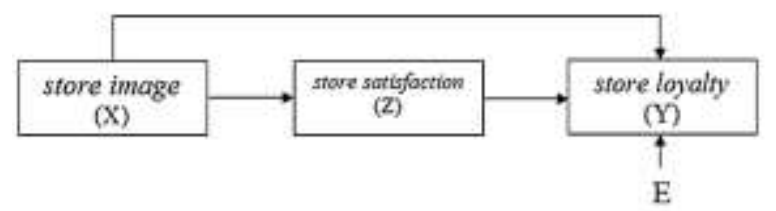

Figure 1. Research Model

\section{T test and coefficient of determination $\left(\mathbf{R}^{2}\right)$}

Test the significance of individual parameters $(t$ test) is used to determine whether there is influence between variables, while $\mathrm{R} 2$ test to determine how much influence it has.

\section{RESULTS AND DISCUSSION}

\section{Validity test}

Validity test is done to measure the extent to which statements in the questionnaire can measure the indicators you want to measure. A statement is said to be valid if the value of $\mathrm{r}$ count $>0.361$ ( 30 respondents), 
and vice versa. Based on the pre-test it was found that all statements in the questionnaire were valid, as follows:

Table 2. Test Results for Validity

\begin{tabular}{|l|r|l|}
\hline Pernyataan & r hitung & keterangan \\
\hline Store Image & & \\
\hline Pernyataan 1 & 0,783 & Valid \\
\hline Pernyataan 2 & 0,542 & Valid \\
\hline Pernyataan 3 & 0,495 & Valid \\
\hline Pernyataan 4 & 0,656 & Valid \\
\hline Pernyataan 5 & 0,696 & Valid \\
\hline Pernyataan 6 & 0,608 & Valid \\
\hline Satisfaction & & \\
\hline Pernyataan 7 & 0,801 & Valid \\
\hline Pernyataan 8 & 0,778 & Valid \\
\hline Pernyataan 9 & 0,787 & Valid \\
\hline Pernyataan 10 & 0,813 & Valid \\
\hline Loyalty & & \\
\hline Pernyataan 11 & 0,897 & Valid \\
\hline Pernyataan 12 & 0,884 & Valid \\
\hline Pernyataan 13 & 0,783 & Valid \\
\hline
\end{tabular}

\section{Reliability Test}

Reliability testing is done to find out whether the measuring instrument has consistency in making measurements. Variables are said to be reliable if they have the value of Cronbach's Alpha> 0.6. Based on the pre-test it was found that all variables were reliable, as follows:

Table 3 Reliability Test Results

\begin{tabular}{|l|r|}
\hline Variabel & Nilai Cronbach's Alpha \\
\hline Store Image & 0,698 \\
\hline Satisfaction & 0,797 \\
\hline Loyalty & 0,815 \\
\hline
\end{tabular}

\section{Path Analysis}

Path analysis is done in 2 stages, stage I is to test the effect of independent variables on intervening variables, then stage II tests the effect of independent and intervening variables on the dependent variable.

\section{Phase I}

In stage I, a test was conducted to measure the indirect effect between the independent variable $(X)$ on the intervening variable $(Z)$. Based on the results of the regression test using statistical software, the following results are obtained:

Table 4. Stage I Regression Path Analysis Test Results for variable $\mathrm{Z}$

\begin{tabular}{|l|l|l|}
\hline \multicolumn{1}{|c|}{ Variabel } & $\begin{array}{c}\text { Std.Coeffients } \\
\text { Beta }\end{array}$ & Signifikansi \\
\hline X (store image) & 0,454 & 0,000 \\
\hline Koefisien Determinasi & $\mathrm{R}^{2}=0,206$ \\
\hline
\end{tabular}

Regression Test Results give the following results:
- Variable X (store image) has a significant influence on the variable $\mathrm{Z}$ (satisfaction), with a significance value in the order of 0,000

- The value of the beta coefficient standard is 0.454 , which means that if the variable increases, customer satisfaction will increase (directly proportional).

- The coefficient of determination is 0.206.

- The contribution variable store image $(X)$ which directly affects customer Satisfaction $(\mathrm{Z})$ of $0.4542=$ 0.2061 or $20.6 \%$. The simultaneous contribution of $\mathrm{X}$ variables which directly affect the $\mathrm{Z}$ variable is 0.206 or $20.6 \%$ and the remaining $79.4 \%$ is influenced by other variables. The value of $\rho z \varepsilon 1$ is equal to $\sqrt{1-R^{2}}=\sqrt{1-0,2 \otimes 6} \sqrt{0,794}=0,891$

Results of calculation of substructure I as follows:

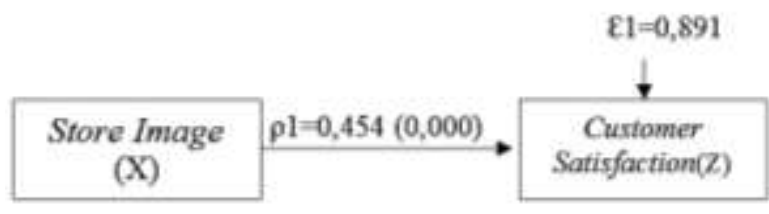

Figure 2. Phase I structure

Substructure I:

$$
\begin{aligned}
Z & =\rho z X+\varepsilon 1 \\
& =0.454 X+0.891 \varepsilon 1
\end{aligned}
$$

Based on the results above, it can be concluded that there is a significant influence between the Store Image $(\mathrm{X})$ variable on customer satisfation (Z).

\section{Phase II}

In stage II, a test is conducted to measure the direct effect between the independent variable (X) and the intervening variable $(\mathrm{Z})$ on the dependent variable (Y). Based on the results of the regression test using statistical software, the following results are obtained:

Table 5 Stage II Path Analysis Regression Test Results for variable $\mathrm{Y}$

\begin{tabular}{|l|l|l|}
\hline \multicolumn{1}{|c|}{ Variabel } & \multicolumn{1}{|c|}{$\begin{array}{c}\text { Std.Coeffients } \\
\text { Beta }\end{array}$} & Signifikansi \\
\hline X-Store Image & 0,341 & 0,001 \\
\hline Z-Customer Satisfaction & 0,264 & 0,008 \\
\hline Koefisien Determinasi & $\mathrm{R}^{2}=0,268$ \\
\hline
\end{tabular}

Regression Test Results give the following results:

- $\mathrm{X}$ and $\mathrm{Z}$ variables have a significant influence on the $\mathrm{Y}$ variable, with a significance value in the order of 0.001 and 0.008 .

- $\mathrm{X}$ and $\mathrm{Z}$ variables have a positive effect seen from the value of the beta standard coefficient in the order of 0.341 and 0.264 for the $Y$ variable which means that 
if these variables increase then loyalty will increase (directly proportional).

- The coefficient of determination (R2) is 0.268 .

Store Image variable contribution that directly affects loyalty (Y) is $0.3412=0.1162$ or $11.6 \%$. Customer variable contribution Satisfaction (Z) which directly affects $\mathrm{Y}$ by $0.2642=0.069$ or $6.9 \%$. Simultaneous contribution of variables $\mathrm{X}$ and $\mathrm{Z}$ which directly affects the $\mathrm{Y}$ variable is 0.268 or $26.8 \%$ and the remaining $73.2 \%$ is influenced by other variables. The value of $\rho z \mathcal{E} 2$ is equal to $\sqrt{1-R^{2}}=\quad \sqrt{1-\emptyset,(2,682}$ $=0,855$.

The results of calculation of substructure II are as follows:

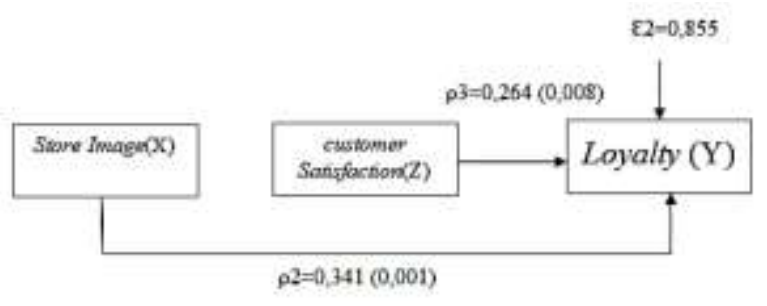

Figure 3. Phase II Substructure

Substructure II:

$$
\begin{aligned}
Y & =\rho y X+\rho y Z+\varepsilon 2 \\
& =0.341 X+0.264 Z+0.855 \varepsilon 2
\end{aligned}
$$

Based on the results above, it can be concluded that there is a significant influence between the Store Image $(\mathrm{X})$ variable and customer satisfaction $(\mathrm{Z})$ on loyalty (Y).

\section{Combined Path Analysis and Phase 1 and Phase II}

Based on the stages I and stage II tests, the combined structure is obtained as follows:

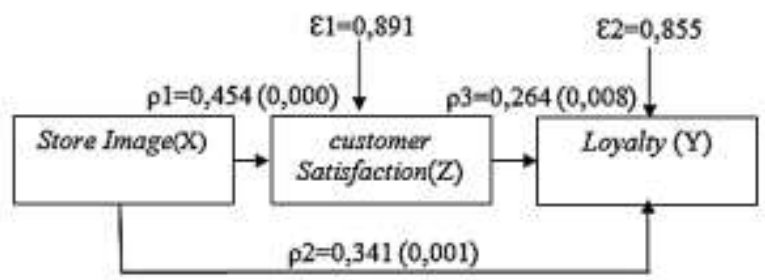

Figure 4. Combined Structure

From Figure 4 it can be seen that there is an indirect influence between the Store Image $(X)$ variable on loyalty (Y) through customer Satisfaction (Z), with the following calculations:

The effect of store smage (X) on store loyalty (Y) through customer satisfaction $(\mathrm{Z})$ is known by multiplying $\rho 1$ by $\rho 3$, which is equal to $0.454 \times 0.264=$
0.119856. The total effect is known by summing the value with the direct effect of store Image (X5) on store loyalty (Y) which is 0.341 so the value is $0.119856+$ $0.341=0.460856$. Next, a comparison between the direct influence and indirect influence is made by comparing the results of the two so that $0.119856<0.341$ is obtained. Thus it is known that the indirect effect of store image $(\mathrm{X})$ on store loyalty $(\mathrm{Y})$ through customer satisfaction (Z) is smaller than the direct effect of store image (X) on store loyalty (Y).

The following table results of the overall calculation based on previous calculations:

Table 6 Calculation of Influences

\begin{tabular}{|l|l|l|l|}
\hline Variabel & $\begin{array}{l}\text { Direct } \\
\text { Effect }\end{array}$ & $\begin{array}{l}\text { Indirect } \\
\text { Effect }\end{array}$ & Total Effect \\
\hline $\mathrm{X} \rightarrow \mathrm{Z}$ & 0,454 & - & - \\
\hline $\mathrm{X} \rightarrow \mathrm{Y}$ & 0,341 & - & - \\
\hline $\mathrm{Z} \rightarrow \mathrm{Y}$ & 0,264 & - & - \\
\hline $\mathrm{X} \rightarrow \mathrm{Z} \rightarrow \mathrm{Y}$ & - & 0,119856 & 0,460856 \\
\hline
\end{tabular}

Based on the results of the statistics above, it is known that store image can directly influence store loyalty, besides being able to influence indirectly through satisfaction. Consumers will be loyal if SMM tries to improve Store Atmosphere, Convenience Facilities, Price, Merchandising, Service Quality, Location.

Consumer loyalty that we expect is not just loyalty because behavior / behavior often buys, but loyalty is also built because there is an attitude of loyalty / attitudinal loyalty to a good store image and satisfaction from using the service.

Store image affects store satisfaction, where the better the image is, it will strengthen customer satisfaction in enjoying shopping activities so that positive habits are built to continue shopping at the store

On the other hand, it turns out that store image can also affect store loyalty, because a good store image will affect consumer attitudes towards reputation, confidence in the store. The better and maintained store image will further strengthen loyalty to the store.

Store satisfaction will affect store loyalty. Shop loyalty is generated by the satisfaction of consumers for shopping at the store, so they want to continue shopping at the SMM store when there is a need / desire. Store satisfaction in shopping activities will affect store loyalty, and this satisfaction is satisfaction arising from behavior / behavioral loyalty for shopping activities in SMM.

Store image affects store loyalty through store satisfaction. With a good store image will build satisfaction so that customers become loyal to continue shopping, have positive attitudes and beliefs for the store.

Looking at the results of research and discussion, it can be said that building loyalty to stores (store loyalty), can be built with a store image that will build customer 
satisfaction, positive attitudes and consumer beliefs about this store.

\section{CONCLUSION}

Based on the research and discussion that has been done, it can be concluded the following matters:

1. Store image has an effect on customer Satisfaction in SMM. Various images attached to the store will give satisfaction to customers when shopping.

2. Store image has an effect on loyalty. The image attached to the store will generate loyalty to its customers.

3. Customer satisfaction affects loyalty. Customer satisfaction will encourage higher consumer loyalty.

4. Store image affects loyalty through customer satisfaction. Store image through customer satisfaction has an influence on consumer loyalty

\section{REFERENCES}

[1] Darmawan, A.I. 2016. SMM Daarut Tauhiid, Wakaf Produktif yang Sehati. http://www.daaruttauhiid.org. Diakses pada 10 Juni 2017.

[2] Martineau, P. 1958. The Personality of the Retail Store. Harvard Business Review, Vol. 36: 47:55.

[3] Bloemer, J., dan K.D. Ruyter. 1998. On the relationship between store image, store satisfaction and store loyalty. European Journal of Marketing. Vol. 32, No. 5/6: 499-513.

[4] Sopiah dan Syihabudhin. 2008. Manajemen Bisnis Ritel. Penebirt ANDI. Yogyakarta.

[5] Kunkel, J.H., dan Berry, L.L. 1968. A Behavioral Conception of Retail Image. Journal of Marketing (pre-1986), Vol. 32: 21-27.

[6] Sezgin, M. dan Küçükköylü, S. 2014. Store's Atmosphere's Importance in Creating Store's Image in Sustainable Management of Store and a Research in Konya(Turkey) City. Journal of Advanced Management Science, Vol 2, No. 3:186191.

[7] Koo, D.M. 2003. Inter-relationships among store images, store satisfaction, and store loyalty among Korea discount retail patrons. Asia Pacific Journal of Marketing and Logistics, Vol. 15 No. 4:42-71. [8]

Hosseini, Z., Jayashree, S. dan Malarvizhi, C. 2014. Store Image and Its Effect on Customer Perception of Retail Stores. Asian Social Science, Vol. 10, No 21:223-235.

[9] Guduk, S. 2016. Store Image, Store Satisfaction, and Store Loyalty: A comparison between Traditional Supermarkets and Hard Discounters. Erasmus University Rotterdam.
[10] Knox, S. D. dan Walker, D. 2001. Measuring and Managing Brand Loyalty. Journal of Strategic Marketing, Vol. 9: 111-128.

[11] Santoso, S. 2009. Store image, store satisfaction, dan store loyalty dalam kegiatan belanja konsumen. Jurnal Manajemen \& Bisnis, Vol. 8 No. $1: 32-45$

[12] Oliver, R.L., dan Desarbo, W.S. 1988. Response Determinants in Satisfaction Judgements. Journal of Consumer Research, Vol. 14: 495-507.

[13] Kotler, P., Keller, K. L. 2010. Marketing Management. Pearson Education Ltd.USA.

[14] McQuitty, S., Finn, A., dan Wiley, J. B. 2000. Systematically Varying Consumer Satisfaction and its Implications for Product Choice. Academy of Marketing Science Review, Vol. 2000, No. 10:116.

[15] Bitner, M.J. 1990. Evaluating Service Encounters: The Effects of Physical Surroundings and Employee Responses.Journal of Marketing, Vol. 54: 69-82.

[16] Keller, K. L. 1993. Conceptualizing, measuring, and managing customer-based brand equity. Journal of Marketing, Vol. 57, No. 1:1-22

[17] Lupiyoadi, Rambat. 2001. Manajemen Pemasaran Jasa. Salemba Empat, Jakarta.

[18] Martenson, R. 2007. Corporate brand image, satisfaction and store loyalty: A study of the store as a brand, store brands and manufacturer brands. International Journal of Retail \& Distribution Management, Vol. 35, No. 7: 544-555.

[19] Theodoridis, P.K. dan Chatzipanagiotou, K.C. 2009. Store image attributes and customer satisfaction across different customer profiles within the supermarket sector in Greece. European Journal of Marketing, Vol. 43, No. 5/6: 708-734.

[20] Agustin, Sasi. Budiyanto dan Ridwan, Mochammad. 2011. Kepuasan Pelanggan Memediasi Hubungan Store Image dan Ekspektasi Pelanggan terhadap Loyalitas Pelanggan. Sekolah Tinggi Ilmu Ekonomi Indonesia. Surabaya.

[21] Orth, U.R. dan Green, M.T. 2009. Consumer loyalty tofamily versus non-family business: The roles of store image, trust and satisfaction. Journal of Retailing and Consumer Services, Vol.16: 248259

[22] Guenzi, P. Dan Pelloni, O. 2004. The impact of interpersonal relationships on customer satisfaction and loyalty to the service provider. International Journal of Service Industry Management, Vol. 15, No 3/4:365-384. 